Research article

urn:1sid:zoobank.org:pub:9F648B8F-D4DC-4B14-A921-673D50F93CCA

\title{
A new cypridopsine genus (Crustacea, Ostracoda) from Thailand
}

\author{
Sukonthip SAVATENALINTON \\ Department of Biology, Faculty of Science, Mahasarakham University, \\ Maha Sarakham 44150, Thailand. \\ Email: sukonthip.s@msu.ac.th \\ urn:1sid:zoobank.org:author:254994A1-C8E1-4242-ADF8-184661366B2D
}

\begin{abstract}
A new cypridopsine genus, Cyprettadopsis gen. nov., described here, is principally characterized by the reduced caudal ramus, the strongly serrated claw G2 of the antenna (A2), the A2 subquadrate terminal segment, the undivided penultimate segment of the second thoracopod (T2), the morphology of the third thoracopod bearing a distinctly separated terminal segment, the complete septa on the posteroventral margin and the incomplete septa on the anterior margin of both valves. Based on a combination of these characters, a new tribe, Cyprettadopsini trib. nov., is created in the subfamily Cypridopsinae Kaufmann, 1900 to accommodate this new genus, and one new species, Cyprettadopsis sutura gen. et sp. nov., is described as the type species. Apart from the above generic characters, the following features are also typical of the new species: the tiny needlepoint-like pores along the anterior and ventral margins of both valves, the remarkably large $\beta$-seta on the mandibular palp and the considerably short $\mathrm{d} 2$ seta on the $\mathrm{T} 2$. The presence of marginal septa in the new genus is a distinctive character and constitutes the first record of this feature within Cypridopsinae. The taxonomically relevant characters in the new taxon and related taxa are briefly discussed.
\end{abstract}

Keywords. Cypridopsinae, crustacean, taxonomy, biodiversity, Southeast Asia.

Savatenalinton S. 2020. A new cypridopsine genus (Crustacea, Ostracoda) from Thailand. European Journal of Taxonomy 631: 1-16. https://doi.org/10.5852/ejt.2020.631

\section{Introduction}

The primary taxonomic character of the subfamily Cypridopsinae Kaufmann, 1900 is the reduced caudal ramus. This subfamily is composed of 19 genera and divided into three tribes: Cypridopsini Kaufmann, 1900, Potamocypridini Ghetti \& McKenzie, 1981 and Zonocypridini Higuti \& Martens, 2012 (Higuti \& Martens 2012; Savatenalinton 2018a). While most genera belong to the Cypridopsini, only one genus (Potamocypris Brady, 1870) and three genera (Cabelodopsis Higuti \& Martens, 2012, Thaicypridopsis Savatenalinton, 2018 and Zonocypris Müller, 1898) are members of the Potamocypridini and Zonocypridini, respectively. In addition, the subfamily Oncocypridinae De Deckker, 1979 (family Notodromadidae Kaufmann, 1900) was proposed to be the fourth tribe of the Cypridopsinae, principally 
due to the presence of a reduced caudal ramus (Diaz \& Martens 2018; Savatenalinton 2018a). However, thus far, it has been kept in Notodromadidae (see Meisch et al. 2019).

In the Thai ostracod checklist, four species of Cypridopsinae (Cypridopsis vidua (O.F. Müller, 1776), Potamocypris sp., Zonocypris sp. 1 and Zonocypris sp. 2), together with unidentified taxa of this subfamily, were presented (Savatenalinton \& Suttajit 2016). The unidentified cypridopsine group contained at least five species of a newly described genus, Siamopsis Savatenalinton, 2017 (Savatenalinton 2017b). Zonocypris sp. 1 was subsequently described as a new taxon (Thaicypridopsis longispinosa Savatenalinton, 2018) (Savatenalinton 2018a), while Zonocypris sp. 2. will be described in the present contribution as a new genus and species.

\section{Material and methods}

Samples were obtained from 313 localities, mainly in the northern and northeastern parts of Thailand during 2005-2017. Samples were taken with a hand net (mesh size $200 \mu \mathrm{m}$ ), immediately preserved in $70 \%$ ethanol and then sorted using a binocular microscope in the laboratory. Soft parts were dissected in glycerine under a stereo microscope (Olympus SZ-PT) and later sealed on glass slides. Valves were stored dry in micropalaeontological slides. A camera lucida, attached to a compound microscope, was used for the drawing of soft parts. Carapaces and valves were observed and illustrated using a scanning electron microscope (a JEOL JSM6460LV at the Faculty of Science, Mahasarakham University, Thailand and a Fei Qanta 200 SEM at the Royal Belgian Institute of Natural Sciences, Brussels, Belgium). The chaetotaxy of the limbs follows the model proposed by Broodbakker \& Danielopol (1982), revised for the A2 by Martens (1987) and for the thoracopods by Meisch (2000). All type material has been deposited in the ostracod collection in the museum of the Faculty of Science, Mahasarakham University, Maha Sarakham, Thailand.

\section{Abbreviation used in text and figures}

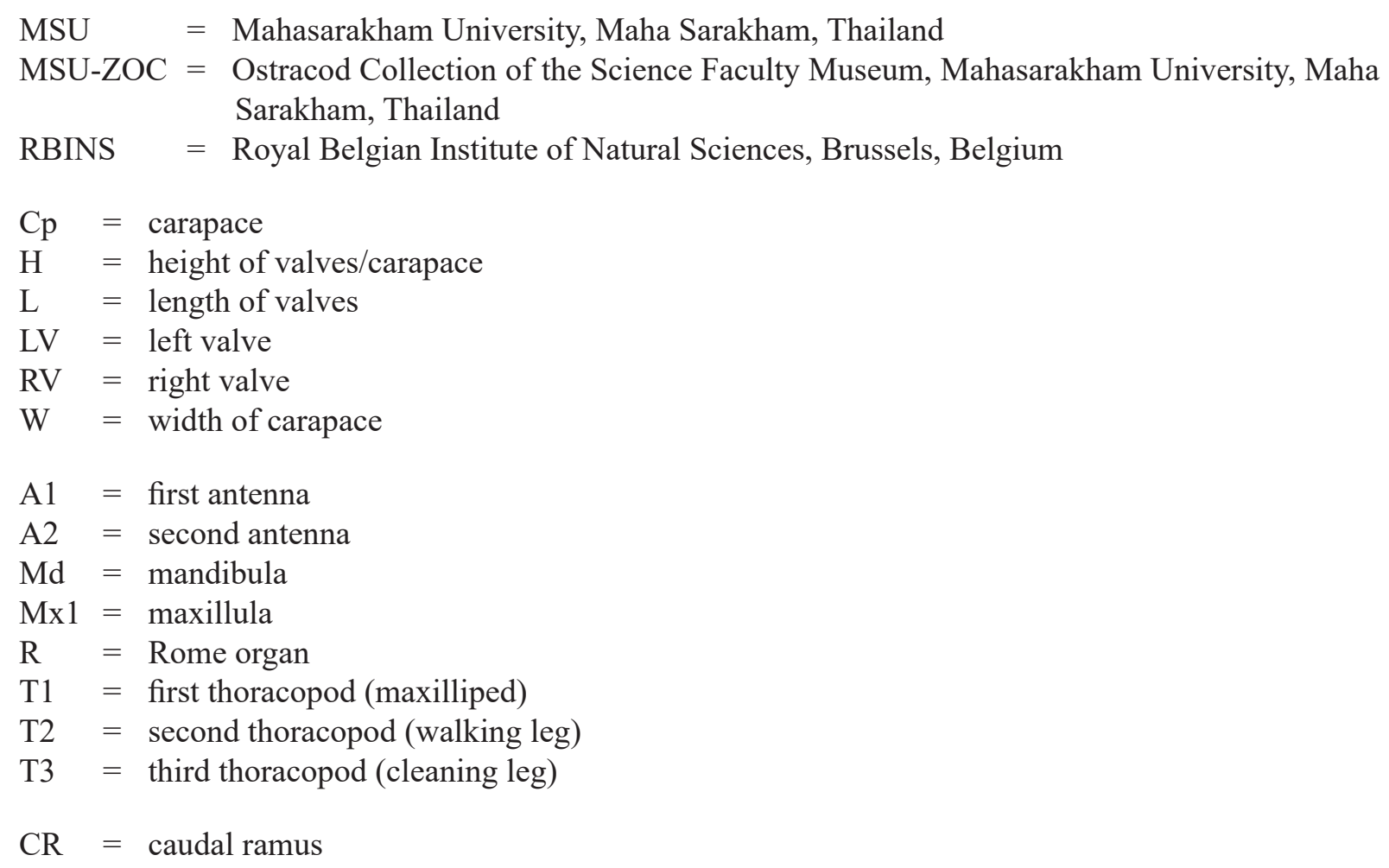




\title{
Results
}

\author{
Class Ostracoda Latreille, 1802 \\ Subclass Podocopa G.O. Sars, 1866 \\ Order Podocopida G.O. Sars, 1866 \\ Suborder Cypridocopina G.O. Sars, 1866 \\ Superfamily Cypridoidea Baird, 1845 \\ Family Cyprididae Baird, 1845 \\ Subfamily Cypridopsinae Kaufmann, 1900 \\ Cyprettadopsini trib. nov. \\ urn:Isid:zoobank.org:act:C70EDD97-8108-44C8-8781-F45ACDD38742
}

\section{Diagnosis}

Cp in lateral view subovate or subtriangular, LV overlapping RV anteriorly and ventrally. RV and LV with (complete or incomplete) marginal septa. LV with large and double posterior inner list, A1 sevensegmented. A2 short and stout, penultimate segment undivided, claw G2 strongly serrated apically. Terminal segment of Mx1 palp elongated. T1 with a-setae (b-, c- and d-setae absent). T2 with $\mathrm{d} 2$ seta (d1 seta absent), penultimate segment undivided. Terminal segment of T3 completely separated from third segment. CR reduced, with flagellum-like distal claw.

\section{Genera included}

Cyprettadopsis gen. nov.

Cyprettadopsis gen. nov. urn:1sid:zoobank.org:act:50B95F11-43AC-43B5-9A83-37B269779BD1

\section{Type species}

Cyprettadopsis sutura gen. et sp. nov. (here designated).

\section{Etymology}

The name is a combination of 'Cypretta' and an abbreviation of the suffix of the existing generic name 'Cypridopsis' to refer to the presence of combined characters between Cypretta and cypridopsine genera.

\section{Diagnosis}

$\mathrm{Cp}$ in lateral view subtriangular, $\mathrm{Cp}$ in dorsal view subelliptical; $\mathrm{LV}$ and $\mathrm{RV}$ in internal view with broad anterior calcified inner lamella, posterior one narrow or absent, LV with one anterior inner list, double posterior inner list, the latter not parallel to valve margin at posteroventral part, RV with large posterior selvage, LV overlapping RV anteriorly and ventrally, complete marginal septa on posteroventral part of both valves, incomplete septa (septa-like structure) on anterior part of both valves, valve surface smooth or set with (shallow) pits; A1 seven-segmented, A2 with undivided penultimate segment, strongly serrated claw G2 and subquadrate terminal segment; terminal segment of Mx1 palp elongated; 11 with a-setae (b-, c- and d-setae absent); T2 penultimate segment undivided, d2 on T2 present (d1 absent); T3 with completely separated terminal segment and very long h1 and h2 setae; CR reduced, with cylindrical base and flagellum-like distal claw.

\section{Differential diagnosis}

Based on the reduced CR and the strongly serrated claw G2 of the A2, Cyprettadopsis gen. nov. is similar to genera in the tribe Zonocypridini Higuti \& Martens, 2012 (Cabelodopsis, Thaicypridopsis 
and Zonocypris). The new genus can be principally distinguished by the presence of marginal septa, the undivided penultimate segment of the T2 and the obvious terminal segment of the T3.

\section{Distribution}

Thailand (present study).

$$
\begin{aligned}
& \text { Cyprettadopsis sutura gen. et sp. nov. } \\
& \text { urn:1sid:zoobank.org:act:DE72C4CD-EC69-459D-A285-29DDB6A07C1C }
\end{aligned}
$$

Figs $1-5$

\section{Etymology}

The specific epithet 'sutura' meaning 'suture' refers to the prominent appearance of tiny, needlepointlike pores along the anterior and ventral margins of both valves that look like a line of fabric suture.

\section{Material examined}

\section{Holotype}

THAILAND - Phayao Province $\bullet$ (soft parts dissected in glycerine on a sealed glass slide and valves stored dry in a micropalaeontological slide); Mae Jai District, Mae Puem Reservoir; 19²1'27.0" N, 9952'06.4" E; 24 Sep. 2005; MSU-ZOC.267.

\section{Paratypes}

THAILAND - Phayao Province $\bullet 1 q$ (stored as the holotype); same collection data as for holotype; MSU-ZOC.268 2 우 (carapaces stored dry in micropalaeontological slides); same collection data as for holotype; MSU-ZOC.269 to 270. - Phitsanulok Province 11 ( (stored as the holotype); Wat Bot District, roadside canal; $17^{\circ} 01^{\prime} 48.9^{\prime \prime} \mathrm{N}, 100^{\circ} 18^{\prime} 51.2^{\prime \prime} \mathrm{E}$; 11 Nov. 2006; MSU-ZOC.271 • 1 q (carapace stored dry in micropalaeontological slide); same collection data as for preceding; MSU-ZOC.272. Ubon Ratchathani Province 1 \& (stored as the holotype); Phibun Mangsahan District, Kaeng Saphue, stony river; $15^{\circ} 14^{\prime} 32.0^{\prime \prime} \mathrm{N}, 105^{\circ} 14^{\prime} 37.9^{\prime \prime} \mathrm{E}$; 24 Oct. 2010; MSU-ZOC.273・19 우 (in 70\% ethanol); same collection data as for preceding; MSU-ZOC.274.

\section{Accompanying ostracod fauna}

Type locality - Bradleystrandesia weberi (Moniez, 1892), Bradleytriebella lineata (Victor \& Fernando, 1981), Chrissia ceylonica (Daday, 1898), Cypretta aculeata Savatenalinton, 2018, Dentocypria chantaranothaii Savatenalinton, 2017, Pseudocypretta maculata Klie, 1932, Pseudostrandesia striatoreticulata (Klie, 1932), Strandesia kraepelini (Müller, 1906).

Other localities - Phitsanulok Province - Wat Bot District, roadside canal; 11 Nov. 2006; Bradleystrandesia weberi, Chrissia sp., Cypretta aculeata, Dentocypria aequiloba Savatenalinton, 2017, Pseudostrandesia mamarilorum (Victor \& Fernando, 1981), Stenocypris orientalis Victor \& Fernando, 1981, Strandesia kraepelini. - Ubon Ratchathani Province - Phibun Mangsahan District, Kaeng Saphue (stony river); 24 Oct. 2010; Chrissia sp., Pseudocypretta maculata, Pseudostrandesia calapanensis (Tressler, 1937), P. gaetani Savatenalinton \& Martens, 2010, Strandesia kraepelini, S. sexpunctata Klie, 1932, Thaicypridopsis longispinosa Savatenalinton, 2018.

\section{Diagnosis}

$\mathrm{Cp}$ in lateral view subtriangular, with maximum height situated at mid-length, anterior and posterior ends subequally rounded. Cp in dorsal view subelliptical, with maximum width situated slightly behind midlength. LV obviously overlapping RV anteriorly and ventrally, RV slightly overlapping LV posteriorly. Complete marginal septa on posteroventral part of both valves, incomplete septa (or septa-like structure) on anterior part of both valves, tiny needlepoint-like pores present along anterior and ventral margins 
of both valves. LV with one anterior inner list, double posterior inner list, the latter not parallel to valve margin at posteroventral part. RV with large posterior selvage. Valve surface with shallow pits around mid-length of $\mathrm{Cp}$ and with sparse thin setae. A2 with long natatory setae, subquadrate terminal segment, claw G2 slender and strongly serrated apically; $\beta$-seta on Md palp very large, two large bristles on Mx1 third endite smooth, terminal segment of Mx1 palp cylindrical (ca 1.3 times as long as wide); b-, c- and d-setae on T1 absent; T2 penultimate segment not divided, d2 seta present in remarkably short length, d1 seta absent; T3 with distinctly separated terminal segment, markedly long h2 seta (ca $3 / 4$ of length of penultimate segment) and long h1 seta (length ca half that of h2 seta); CR reduced, with cylindrical base, laterally with short seta and flagellum-like distal claw.

\section{Differential diagnosis}

At first glance, Cyprettadopsis sutura gen. et sp. nov. resembles Cypridopsis gibba and Cypridopsis tumidula (see Sars 1910) because of the external morphology of its carapace, especially the shape. However, Cyprettadopsis sutura gen. et sp. nov. is apparently separated from them by the presence of marginal septa. In addition, other discriminating characters are also recognized in the new species, namely the tiny needlepoint-like pores along the anterior and ventral margins of both valves, the T2 undivided penultimate segment, the considerably short $\mathrm{d} 2$ seta on the $\mathrm{T} 2$, the distinctly separated terminal segment of the T3 and the remarkably large $\beta$-seta on the Md palp. A combination of these features is not found in any other cypridopsine species.

\section{Measurements (in $\mu \mathrm{m}$ )}

Cp ( $\mathrm{n}=7): \mathrm{L}=399-416, \mathrm{H}=224-237, \mathrm{~W}=227-240 ; \mathrm{LV}(\mathrm{n}=3): \mathrm{L}=399-416, \mathrm{H}=230-243$; $\mathrm{RV}(\mathrm{n}=3): \mathrm{L}=394-413, \mathrm{H}=227-241$.

\section{Description}

\section{Female}

CP IN LATERAL VIEW (Fig. 1A). Subtriangular, anterior and posterior ends subequally rounded, dorsal margin evenly arched, maximum height situated at mid-length, LV obviously overlapping RV anteriorly and ventrally, RV slightly overlapping LV posteriorly, valve surface with shallow pits around mid-length of $\mathrm{Cp}$ and with sparse thin setae, tiny needlepoint-like pores present along anterior margins of both valves.

CP IN DORSAL VIEW (Fig. 1B). Subelliptical, with evenly curved lateral margins, maximum width situated slightly behind mid-length, posterior extremity round, anterior extremity more pointed.

CP IN VENTRAL VIEW (Fig. 1C-D). With tiny needlepoint-like pores along ventral borders of both valves, except for middle part; LV margin not straight (slightly curved at mid-length).

LV IN INTERNAL VIEW (Fig. 1E). With anterior and posterior valve margins subequally rounded, ventral margin slightly sinuous at mid-length, submarginal selvage anteriorly, anterior calcified inner lamella wide, with one inner list, posterior calcified inner lamella narrow, with double posterior inner list well developed but not parallel to valve margin at posteroventral part. Complete marginal septa on posteroventral part, incomplete septa on anterior part (Fig. 2A).

RV IN INTERNAL VIEW (Fig. 1F). With anterior and posterior valve margins subequally rounded, ventral margin sinuous at mid-length, submarginal selvage anteriorly, anterior calcified inner lamella wide, with incomplete inner list (only on mouth area), posterior calcified inner lamella narrow, with incomplete inner list (only on posteroventral part), posterior selvage moderate. Complete marginal septa on posteroventral part, incomplete septa on anterior part (Fig. 2B). 
A1 (Fig. 3A). Seven-segmented, first segment with one short dorso-subapical seta (reaching tip of next segment) and two long ventro-apical setae. Second segment ca two times as wide as long, with one short dorso-apical seta (reaching $1 / 3$ of next segment) and small Rome organ. Third segment bearing two setae: one long dorso-apical (reaching beyond tip of penultimate segment) and one short ventro-apical setae (reaching half of next segment). Fourth segment with two long dorsal setae and two short ventral setae (both reaching tip of next segment). Fifth segment dorsally with two long setae, ventrally with two (one long, one short) setae, short one reaching half of terminal segment. Penultimate segment with four long apical setae and one short seta (reaching tip of terminal segment). Terminal segment with three (two long, one short) apical setae and long aesthetasc ya, length of aesthetasc ya ca equal to that of last five segments, length of short seta $\mathrm{ca}^{2} / 3$ that of aesthetasc ya.

A2 (Fig. 3B). Basal segment with one long ventro-apical seta. Exopodite with three (one long, two short) setae, long one reaching slightly beyond half of penultimate segment. First endopodal segment with

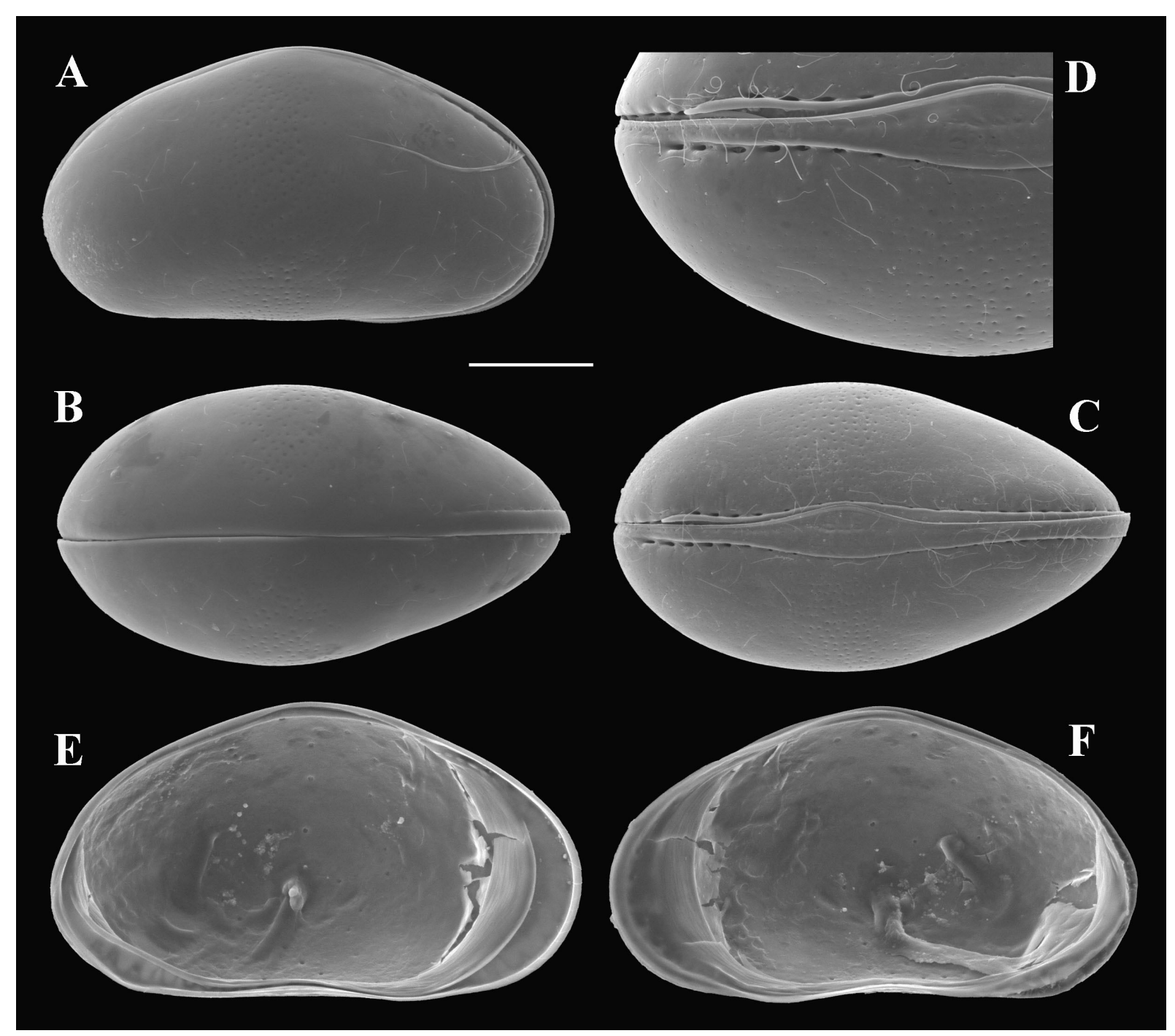

Fig. 1. Cyprettadopsis sutura gen. et sp. nov., ․ A. Cp, right lateral view (MSU-ZOC.269). B. Cp, dorsal view (MSU-ZOC.270). C. Cp, ventral view (MSU-ZOC.269). D. Posterior part of Cp in ventral view (MSU-ZOC.272). E. LV, internal view (MSU-ZOC.268). F. RV, internal view (MSU-ZOC.268). Scale bar: A-C, E-F $=100 \mu \mathrm{m} ; \mathrm{D}=63 \mu \mathrm{m}$. 
five very long setae (reaching far beyond tips of terminal claws) and one short natatory seta, length of shortest seta reaching half of penultimate segment, aesthetasc Y long, ventro-apical seta long, extending beyond tip of terminal segment. Penultimate segment undivided, distally with three large, serrated claws (G1-G3), G2 strongly serrated apically, serration appearing almost half of length, aesthetasc y2 very long (reaching mid-length of aesthetasc y3), z1-z3 setae long, Z1 slightly larger than other z setae, z2-z3 reaching tip of claws G1-G3; this segment medially with two subequally long dorsal setae, four ventral setae of unequal length ( $t 1-t 4)$, one $t$ seta with claw-like appearance. Terminal segment subquadrate, distally with two serrated claws (GM and $\mathrm{Gm}$ ), length of $\mathrm{Gm} \mathrm{ca}^{2} / 3$ that of GM; medially with very short $\mathrm{g}$ seta and ventral aesthetasc $\mathrm{y} 3$, length of aesthetasc $\mathrm{y} 3$ slightly greater than that of accompanying seta.

MD-PALP (Fig. 4A). First segment with two large setae (S1 and S2), one long and slender seta, and a smooth $\alpha$-seta. Second segment dorsally with three unequal, long apical setae, shortest seta reaching tip of next segment; ventrally with group of three long hirsute setae (setules not drawn), one shorter hirsute seta (setules not drawn) and remarkably large, plumose, cone-shaped $\beta$-seta with pointed tip. Penultimate segment bearing three groups of setae: dorsally with group of four unequal, long, subapical setae; laterally with apical $\gamma$-seta and three further apical setae, the former slightly plumose (length ca 2.8 times that of terminal segment); ventrally with two subapical setae, one long (reaching ca $2 / 3$ of terminal claws), one short (ca half of terminal segment). Terminal segment bearing three large claws and three shorter setae, large claws ca three times as long as terminal segment.

MD-COXA (Fig. 4B). Elongated, distally with rows of teeth and small setae, and with one dorso-subapical seta situated close to palp.

Mx1 (Fig. 4C). With two-segmented palp, basal segment of palp dorsally with group of five long, unequal apical setae; ventrally with one long subapical seta (not reaching half of terminal segment), terminal segment elongated (ca two times as long as wide), apically with three claws and two setae. Third endite with two large, pointed-tip bristles (without spatula-shaped apex). Two sideways-directed bristles (one bristle drawn) on first endite long, subequal in length.

T1 (Fig. 4D-E). Protopodite with two a-setae, long one more than two times as long as short one; b-, c- and d-setae absent, distally with ca 10 hirsute apical setae of unequal length, no subapical setae. Endopodite (Fig. 4C) a weakly built palp with one very long, hirsute and two unequally shorter apical setae, length of shortest one less than $1 / 3$ that of long one.

T2 (Fig. 5A). With remarkably short $\mathrm{d} 2$ seta, $\mathrm{d} 1$ absent. Second segment with long e-seta (length ca $2 / 3$ that of penultimate segment). Penultimate segment undivided, medially with long f-seta (reaching beyond tip of terminal segment), distally with very short apical g-seta (not reaching tip of segment).
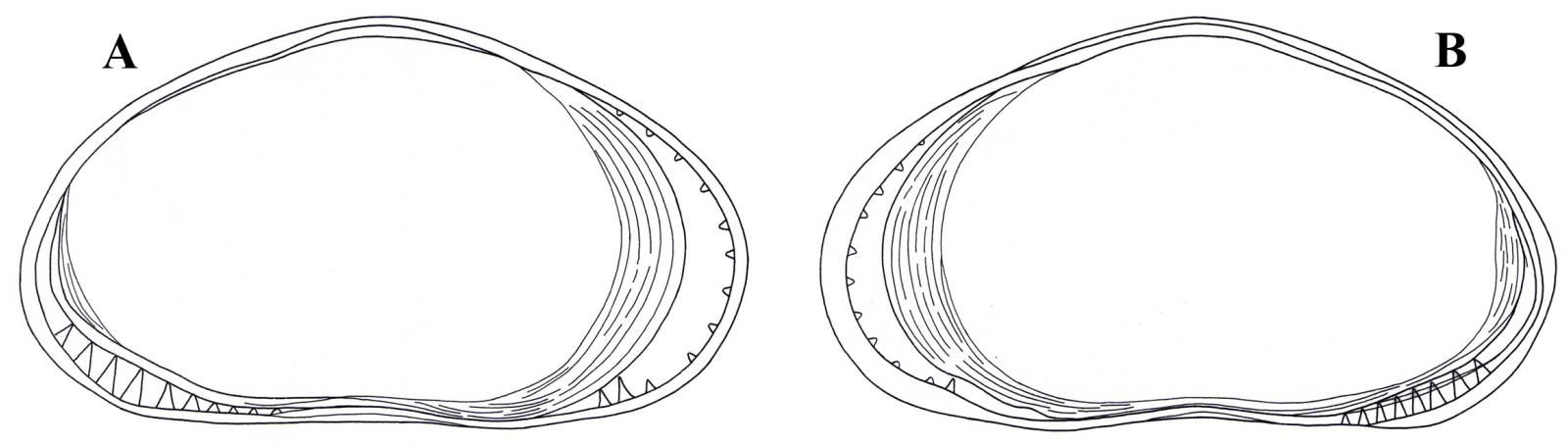

Fig. 2. Cyprettadopsis sutura gen. et sp. nov., $q$ (MSU-ZOC.268), drawn with transmitted light. A. LV, internal view. B. RV, internal view. Scale bars: $100 \mu \mathrm{m}$. 


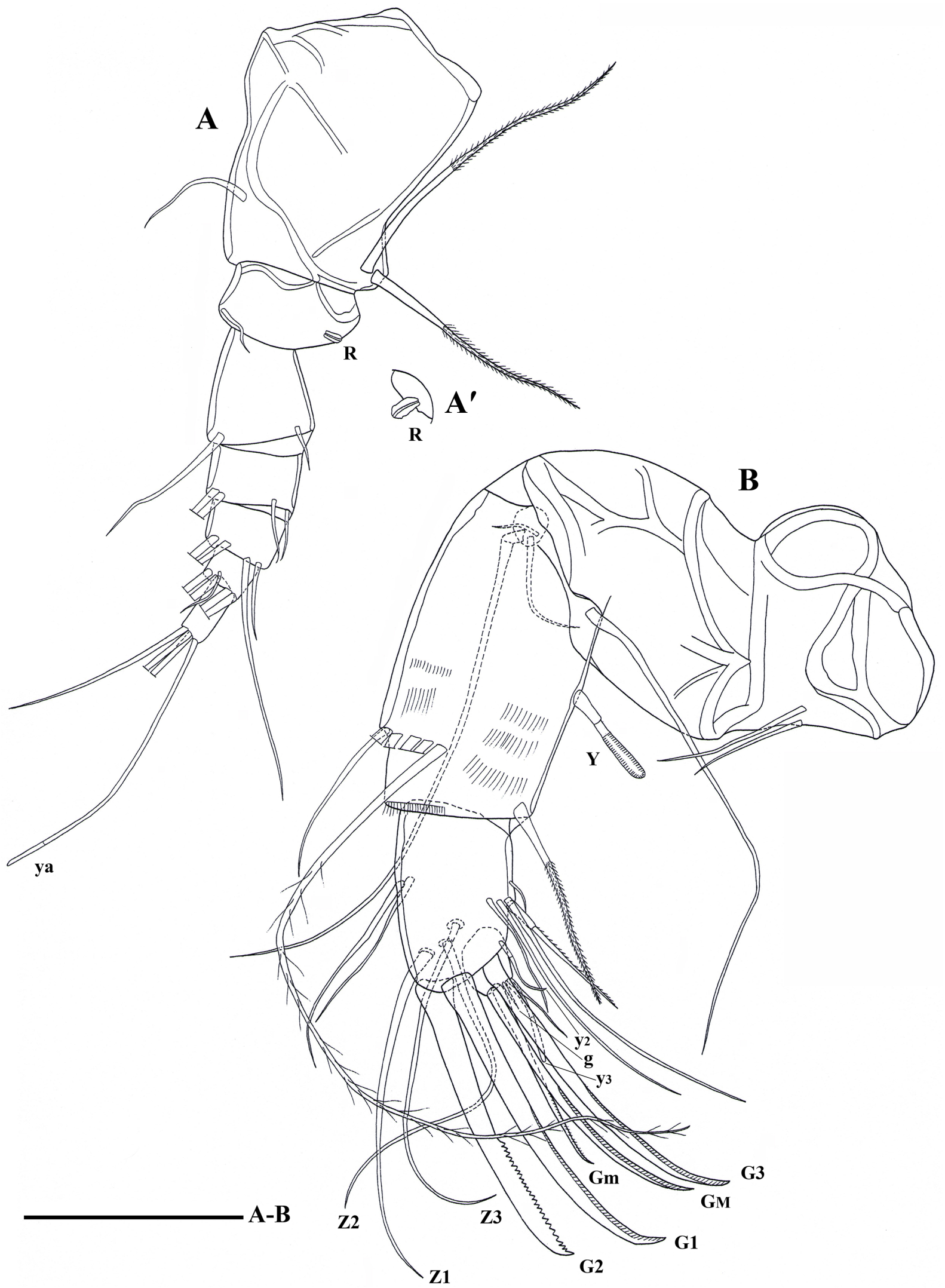

Fig. 3. Cyprettadopsis sutura gen. et sp. nov., q (MSU-ZOC.267). A. A1. A'. Rome organ of A1. B. A2. Scale bar: $50 \mu \mathrm{m}$. 


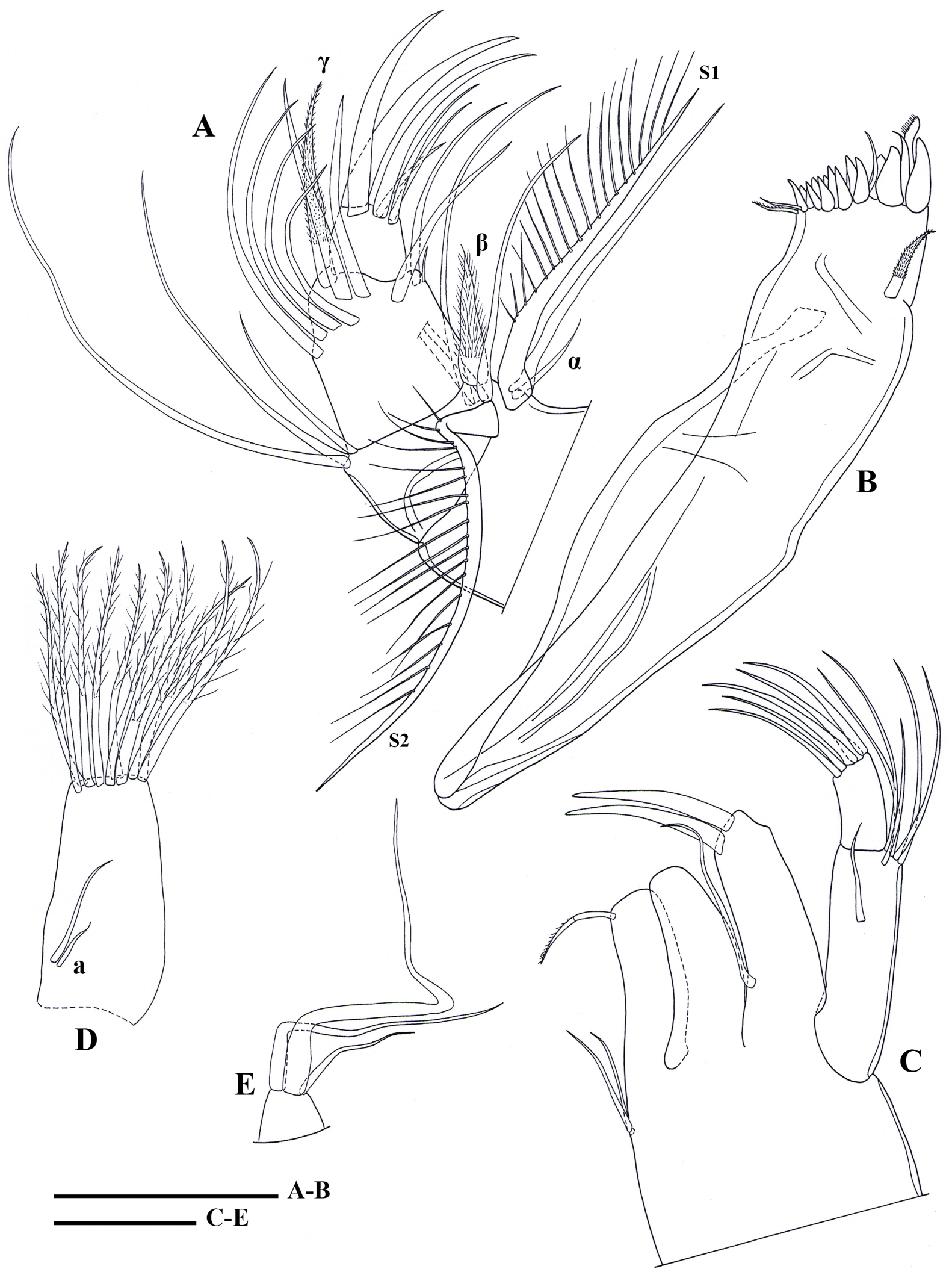

Fig. 4. Cyprettadopsis sutura gen. et sp. nov., q. A-D. MSU-ZOC.267. A. Md palp. B. Md coxa. C. Mx1, one sideways directed bristle on the first endite is drawn. D. T1. E. Terminal part of T1 endopodite (MSU-ZOC.268). Scale bars: $\mathrm{A}=35 \mu \mathrm{m}$; $\mathrm{B}=50 \mu \mathrm{m}$; $\mathrm{C}-\mathrm{E}=25 \mu \mathrm{m}$. 
Terminal segment with two (one dorsal, one ventral) apical h1 and h3 setae (length of former ca $1 / 3$ that of claw, the latter short) and serrated claw (h2), length of $\mathrm{h} 2$ greater than that of last two segments.

T3 (Fig. 5B). First segment with short $\mathrm{d} 1$ and long $\mathrm{d} 2$ and $\mathrm{dp}$ setae, length of $\mathrm{d} 1$ seta ca half that of $\mathrm{d} 2$ and $\mathrm{d} 3$ setae. Second segment with short apical e-seta (not reaching $1 / 3$ of next segment). Third segment with short f-seta (not reaching tip of segment). Terminal segment completely separated from previous segment, bearing long seta (h1), claw-like seta (h2) and one reflexed subapical seta (h3), h1 reaching half of h2, h2 markedly long (ca 3/4 length of third segment), h3 shorter than $h 2$.

CR (Fig. 5C). Reduced, with cylindrical base, medially with short seta, distal claw flagellum-like, long seta (length ca 1.5 times that of ramus).

\section{Male}

Unknown.

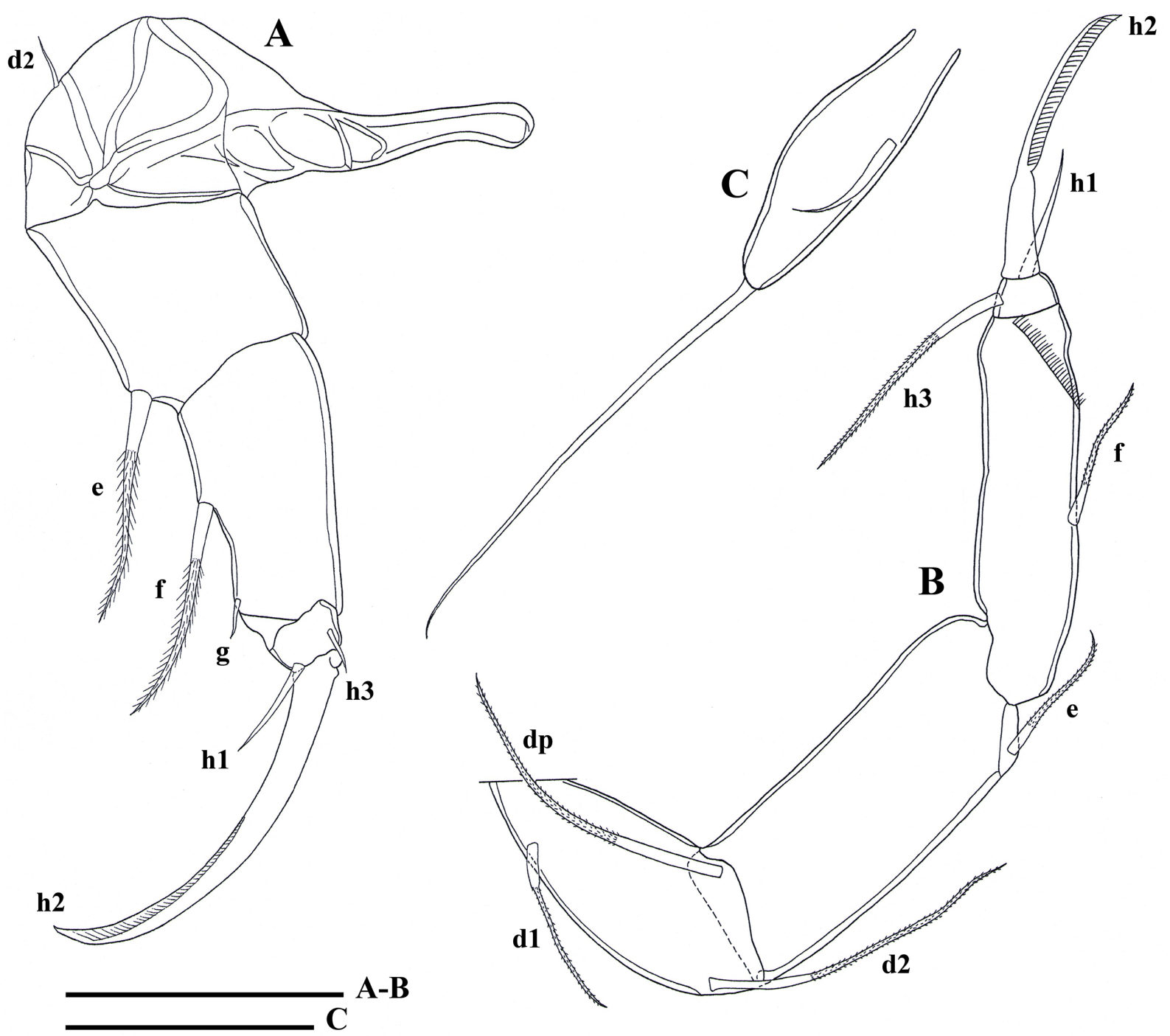

Fig. 5. Cyprettadopsis sutura gen. et sp. nov., ㅇ (MSU-ZOC.267). A. T2. B. T3. C. CR. Scale bars: $\mathrm{A}=50 \mu \mathrm{m} ; \mathrm{B}=40 \mu \mathrm{m} ; \mathrm{C}=25 \mu \mathrm{m}$. 


\section{Remarks}

Cyprettadopsis sutura gen. et sp. nov. was encountered in environments with a temperature range of $20.3-33.7^{\circ} \mathrm{C}$, a pH range of $6.33-9.97$ and a DO range of $2.14-11.54 \mathrm{mg} / \mathrm{l}$. It is considered to be an uncommon species due to its occurrence in only 60 (ca 19\%) of the 313 surveyed localities. The new species was collected in both rainy and dry seasons from a wide range of habitats, namely swamps, (oxbow) lakes, reservoirs, ponds, rice fields, rivers, canals, weirs and streams. The fact that they can inhabit both running and standing waters, as well as permanent and temporary bodies of water, suggests a probably general habit of this species. However, its population size was remarkably small. Small populations of up to 5 specimens recovered per sample were recognized in $52(87 \%)$ of the 60 localities from which the species was recorded. Seven localities harbored slightly larger populations, with specimen counts of 6-10, 15-20, 21-25 and 31-35, respectively, from 3, 2, 1 and 1 localities. Interestingly, one locality (Ban Don Pattana Reservoir, Mukdahan Province) yielded a very high abundance with more than 130 specimens. This sampling site was covered with very few aquatic plants and the substrate was sandy, with moderate organic detritus. The environmental conditions were measured with temperature, $\mathrm{pH}$ and DO being $25.5^{\circ} \mathrm{C}, 7.39$ and $12 \mathrm{mg} / \mathrm{l}$, respectively. As similar aspects of the habitat were also observed at other localities with low abundance, the apparent success of the species in this particular habitat is still unclear and remains to be elucidated by future investigation.

\section{Discussion}

\section{Taxonomic position of Cyprettadopsis gen. nov.}

Cyprettadopsis gen. nov., described here, is mainly characterized by the reduced CR, the strongly serrated claw $\mathrm{G} 2$ of the $\mathrm{A} 2$, the $\mathrm{A} 2$ subquadrate terminal segment, the undivided penultimate segment of the $\mathrm{T} 2$, the completely separated terminal segment of the T3, the complete septa on the posteroventral margin and the incomplete septa on the anterior margin of both valves. The combination of these features in the new genus is considered outstanding, resulting in its higher taxonomic position. Based on the presence of septa, the new genus could be a representative of the Cyprettinae group, which comprises six genera in three subfamilies, namely Batucyprettinae Victor \& Fernando, 1981, Bradycypridinae Hartmann \& Puri, 1974 and Cyprettinae Hartmann, 1971, according to the classification by Meisch et al. (2019). Batucyprettinae was established by Victor \& Fernando (1981a) on the basis of the presence of incomplete septa as the main diagnostic character. This lineage is so far represented by only a single genus and monospecific, Batucypretta paradoxa Victor \& Fernando, 1981. Three genera (Bradycypris Sars, 1925, Paracypretta Sars, 1924 and Zonocypretta De Deckker, 1981) of the subfamily Bradycypridinae are principally united by the presence of complete marginal septa, which is also the co-feature of the two other genera (Cypretta Vávra, 1895 and Pseudocypretta Klie, 1932) in the subfamily Cyprettinae. Septa can be divided into two types, complete and incomplete, depending on whether the septa reach the line of concrescence. Most genera possess only one aspect of septa, either complete (e.g., Cypretta) or incomplete (e.g., Batucypretta Victor \& Fernando, 1981), but, interestingly, both types are recognized in Cyprettadopsis gen. nov., making it different from the others. Although the presence of marginal septa in Cyprettadopsis gen. nov. points towards the Cyprettinae group, a comparison of its soft part morphology reveals that many of its characters render it quite different from these six genera (see, e.g., Sars 1924; De Deckker 1981; Victor \& Fernando 1981a, 1981b; Savatenalinton 2018b). For instance, all of these genera (except Pseudocypretta) have developed a form of the CR which is composed of ramus, claws and setae, whereas in the new genus the CR is reduced, with a flagellum-like distal claw. A strongly serrated claw $\mathrm{G} 2$ of the A2 is present in the new genus, but absent in these three subfamilies. The T2 penultimate segment is undivided in Cyprettadopsis gen. nov., but divided in all genera of the Cyprettinae group, except for Batucypretta. Most genera in the Cyprettinae group have d1 and $\mathrm{d} 2$ setae on the T2, whereas the d1 seta is absent in the new genus. Another outstanding feature of Cyprettadopsis gen. nov. is the morphology of the T3, in which the terminal segment is distinctly separated from the penultimate segment and the $\mathrm{h} 1$ and $\mathrm{h} 2$ setae are markedly long; these $\mathrm{T} 3$ features are missing in the 
Cyprettinae group, except for Batucypretta. Among the genera in the Cyprettinae group, the new genus seems to resemble Batucypretta more than the others.

Cyprettadopsis gen. nov. also shares features with the subfamily Cypridopsinae, especially the reduced $\mathrm{CR}$, the strongly serrated claw $\mathrm{G} 2$ of the $\mathrm{A} 2$ and the absence of a d1 seta on the T2. This combination of features has so far only been found in cypridopsine genera. However, the marginal septa have never been found in Cypridopsinae. In addition, the penultimate segment of the T2 is divided in all cypridopsine genera, whereas it is undivided in the new genus. Also, the morphology of T3 in the new genus, as mentioned above, differs considerably from that of Cypridopsinae, where the terminal segment is fused with the tip of the penultimate segment.

Consequently, according to the morphological comparison explained above, there are two possible subfamilies that could be suitable for the new taxon: Batucyprettinae and Cypridopsinae. The morphology of septa, the T2 penultimate segment and the T3 would place the new genus with the Batucyprettinae, but this allocation is obstructed by the presence of a reduced CR and the strongly serrated claw G2 of the A2. The morphology of the CR and claw G2 of the A2, as well as the absence of a d1 seta on the T2 clearly indicate the new genus as a member of Cypridopsinae. However, the septa, the T2 penultimate segment and the T3 do not conform to the characters of Cypridopsinae. It would seem to be improper to allocate this new genus to Batucyprettinae, because this would cause two types of CR (developed or reduced forms) to occur in the subfamily. CR is a prime diagnostic character used at higher levels of classification, such as family and subfamily. Thus far, there is only one CR type in one subfamily. In addition, the classification should rely primarily on the soft part features, as it appears that the more conservative aspects occur in the anatomy of soft body parts, e.g., the number of segments and the occurrence of setae. Hence, given the fact that the soft part morphology of the new genus exhibits more similarity with that of subfamily Cypridopsinae than with Batucyprettinae, this new taxon is properly assigned as a cypridopsine genus. Although this designation results in Cyprettadopsis gen. nov. having a carapace that is somewhat distinctive from the others in the subfamily, it is not the first such case in the family Cyprididae. A similar phenomenon also exists in the subfamily Herpetocypridinae Kaufmann, 1900, which comprises three tribes (Herpetocypridini Kaufmann, 1900, Stenocypridini Ferguson, 1964 and Psychrodromini Martens, 2001), as marginal septa have only been found in Stenocypris Sars, 1889 within the tribe Stenocypridini. Such occurrences of the presence of septa could be homoplasious, resulting from convergent evolution within these lineages.

The morphology of the T3 in Cyprettadopsis gen. nov. is exceptional, compared to other cypridopsine genera. The allocation of the new genus to Cypridopsinae results in the presence of two forms of the T3 appearing in the same subfamily. This scenario has not previously been recorded in the Cyprididae. These differences of T3 features could possibly be the result of divergent evolution, as the incomplete fusion of the T3 terminal segment is also present in some other cypridopsine genera and species, including the zonocypridinid taxa, the most closely related group to the new genus, including species such as Thaicypridopsis longispinosa (see Savatenalinton 2018a), Zonocypris inconspicua (see Schäfer 1952 ) and $Z$. corrugata (see Rome 1965). The incomplete fusion of the T3 terminal segment could be an intermediate stage of evolution between the complete separation in the new genus and the complete fusion in Cabelodopsis and most species of Zonocypris.

As the septa and the morphology of the T3, together with the undivided penultimate segment of the T2, do not comply with conditions in any cypridopsine tribes, it is therefore appropriate that a new tribe, Cyprettadopsini trib. nov., is established within the Cypridopsinae to accommodate this new taxon. Cyprettadopsis gen. nov. is the third cypridopsine genus described from Thailand, after Siamopsis and Thaicypridopsis. 


\section{Taxonomically relevant characters in Cyprettadopsis gen. nov.}

According to the diagnostic features of Cyprettadopsini trib. nov., the new tribe is closely related to the tribe Zonocypridini mainly with respect to the reduced CR and the strongly serrated claw G2 of the A2. Taxonomically relevant characters in the new taxon and related taxa, especially Zonocypridini, are discussed below.

Obviously, overlap is one of the important morphological characters used for classification, at least at the generic level, such as in the subfamilies Cyprinotinae (see, e.g., Savatenalinton \& Martens 2008; Halse \& Martens 2019), Cypridopsinae (see, e.g., Savatenalinton 2017b, 2018a) and Cyclocypridinae (see, e.g., Savatenalinton 2017a). The RV overlapping the LV has been recorded in most genera of the Cypridopsinae (see Savatenalinton 2017b, 2018a). In Zonocypridini, all genera have the LV overlapping all free margins of the RV. Interestingly, the overlap in Cyprettadopsis gen. nov. is exceptional in that LV overlaps RV anteriorly and ventrally, but a small dextral overlap appears posteriorly.

The following are the features of the $\mathrm{A} 2$ found in all genera of the tribes Cyprettadopsini trib. nov. and Zonocypridini: an undivided penultimate segment, long natatory setae (reaching far beyond the tip of the terminal claws) and an apical strongly serrated claw G2. The latter feature is exceptional and is used as a significant diagnostic character of these two tribes (Higuti \& Martens 2012; Savatenalinton 2018a; present study). However, the serration of claw G2 differs slightly between the genera. For example, in Cabelodopsis it is a series of rounded teeth on the distal two-thirds of the length, while serration is strong, with an apical concavity in Thaicypridopsis. The distal serration on claw G2 covers slightly less than half of the length in Cyprettadopsis gen. nov. It should be noticed that in the new genus this claw is more slender than in Cabelodopsis or Thaicypridopsis. A similar slender claw G2 with distally strong serration can also be recognized in several Zonocypris, e.g., Z. alveolata Klie, 1936 (see Klie 1936), Z. calcarata Klie, 1936 (see Klie 1936), Z. inconspicua Schäfer, 1952 (see Schäfer 1952) and Z. tuberosa G.W. Müller, 1908 (see Sars 1924), while other species of Zonocypris have a large claw G2, e.g., Z. corrugata Rome, 1965 (see Rome 1965), Z. costata (Vávra, 1897) (see Vávra 1897; G.W. Müller 1898) and Z. laevis Sars, 1910 (see Sars 1910). Different degrees of G2 serration and differences in shape are potential diagnostic characters at the species level, at least in Zonocypris. Interestingly, in the new genus, the A2 terminal segment is subquadrate, which differs from conditions in other cypridopsine taxa. However, a similar shape of this segment is seen in Pseudocypridopsis clathrata (Klie, 1936) (see Karanovic 1999) and P. petkovskii Karanovic, 2000 (see Karanovic 2000). In the new genus, this aspect is presently treated as a generic characteristic. The future discovery of new representatives of this new genus may confirm its diagnostic value.

One of the prominent features of Cyprettadopsis sutura gen. et sp. nov. is the markedly large $\beta$-seta on the Md palp, which has not previously been noted in the Cypridopsinae. As the new genus is currently monospecific, a diagnostic character at the generic level is likely to be equivocal. However, some evidence in the Cyprididae seems to indicate that this aspect could be relevant at the specific level due to the fact that this seta is variable in some genera. For instance, the $\beta$-seta is medium-sized in all species of Pseudostrandesia, except for P. mamarilorum sumatrana (Victor \& Fernando, 1981), which shows an exceptionally large $\beta$-seta (see Victor \& Fernando 1981c). A similar situation is also encountered in Strandesia wolterecki Tressler, 1937, which possesses a very large $\beta$-seta (see Victor \& Fernando 1981c) and differs from other representatives of the genus. Another case is recognized in Cypretta in which a very large $\beta$-seta occurs in some species, such as C. turgida Sars, 1896 (see Victor \& Fernando 1981b), C. spinosa Cohuo-Durán et al., 2013 (see Cohuo-Durán et al. 2013) and C. triangulata Savatenalinton, 2018 (see Savatenalinton 2018b). It should also be realized that such notable aspects of the $\beta$-seta are absent in most genera of the family Cyprididae. Thus, the character state of this feature is better suited at the generic level, with exception of some genera.

The occurrences of a-, b-, c- and d-setae on T1 serve as generic characters in several subfamilies, such as Eucypridinae Bronstein, 1947 (Martens et al. 2002) and Cypricercinae G.O. Sars, 1895 (see 
Savatenalinton \& Martens 2009; Ferreira et al. 2019). In the Cypridopsinae, including the new tribe, the presence of a-setae and the absence of b-, c- and d-setae are typical patterns of the T1. Thus, a d-seta is only present in Cabelodopsis. Despite the fact that a-setae are variable among cypridoidean species, they are usually subequal in length. Nevertheless, Cyprettadopsis gen. nov. displays a different pattern in that the length of the long one is more than twice that of the short one.

The absence of the $\mathrm{d} 1$ seta on the T2 is a diagnostic character of Cypridopsinae as it is absent in all genera of the subfamily, including Cyprettadopsis gen. nov. (see also Savatenalinton 2017b). In the new genus, the length of the $\mathrm{d} 2$ seta is remarkably short. Nonetheless, this feature should not be considered diagnostic at the generic level because it can vary among species of the same genus, such as in Cypridopsis (see Meisch 2000) and Potamocypris (see Meisch 2000; George \& Martens 2002; Horne \& Smith 2004).

As mentioned above, the T3 morphology of the new genus is not congruent with that in other genera of Cypridopsine. Apart from Batucypretta (see discussion above), the morphology of this limb in the new genus also resembles that of Oncocypris G.W. Müller, 1898 (in Oncocypridinae De Deckker, 1979, family Notodromadidae Kaufmann, 1900). Additionally, some valve features of the new genus are similar to those of Oncocypris, namely the presence of complete marginal septa and the presence of tiny needlepoint-like pores along the anterior and ventral margins of both valves (see Savatenalinton 2015). The similarity between zonocypridinid taxa and Oncocypris has previously been discussed by Diaz \& Martens (2018) and Savatenalinton (2018a) based on the morphology of Mx1, T2 and CR. Although the characters of the T3, together with the valve morphology, in the new genus are likely to be pieces of evidence supporting the taxonomic status of Oncocypridinae as a tribe in Cypridopsinae (see Diaz \& Martens 2018; Savatenalinton 2018a), the presence of an ocular structure is a prime taxonomic character that unites Oncocypridinae with Notodromadidae (De Deckker 1979).

\section{Acknowledgements}

The samples examined in this study were obtained from several research projects financially supported by the Thailand Research Fund (TRF, contract number MRG5380256), the Office of the Higher Education Commission (OHEC), National Research Council of Thailand (NRCT), Mahasarakham University (contract numbers 5405021, 5505004, 5705022, 5808010 and 6005054) and the Faculty of Science (contract number MSU-SC-53-011) during the years 2009 to 2017. The presentation of this work at the $9^{\text {th }}$ European Ostracodologists' Meeting (EOM9) in Poland was financially supported by Mahasarakham University Development Fund and Faculty of Science, Mahasarakham University, Thailand. Prof. Dr Koen Martens (RBINS, Brussels) is gratefully acknowledged for his invaluable advice. Julien Cillis (RBINS, Brussels) and Nual-arnong Nakkong (MSU, Thailand) offered technical assistance with the scanning electron micrographs. Two anonymous reviewers are thanked for providing useful comments.

\section{References}

Broodbakker N.W. \& Danielopol D.L. 1982. The chaetotaxy of Cypridacea (Crustacea, Ostracoda) limbs: proposals for a descriptive model. Bijdragen tot de Dierkunde 52 (2): 103-120.

https://doi.org/10.1163/26660644-05202003

Cohuo-Durán S., Elías-Gutiérrez M. \& Karanovic I. 2013. On three new species of Cypretta Vávra, 1895 (Crustacea: Ostracoda) from the Yucatan Peninsula, Mexico. Zootaxa 3636 (4): 501-524. https://doi.org/10.11646/zootaxa.3636.4.1

De Deckker P. 1979. Comparative morphology and review of Australian Notodromadinae Kaufmann, 1900. Senckenbergiana Biologica 59: 417-463.

De Deckker P. 1981. Taxonomic notes on some Australian ostracods with description of new species. Zoologica Scripta 10 (1): 37-55. https://doi.org/10.1111/j.1463-6409.1981.tb00483.x 
Diaz A. \& Martens K. 2018. On Argentodromas bellanella gen. nov., sp. nov. (Crustacea, Ostracoda) from a stream in Northeastern Argentina (South America). Zoological Studies 57: e10. https://doi.org/10.6620/ZS.2018.57-10

Ferreira V.G., Higuti J. \& Martens K. 2019. A striking case of convergent evolution in two species of Cypricercinae (Crustacea, Ostracoda), with the description of a new genus and species from Brazil. Zoologischer Anzeiger 283: 1-11. https://doi.org/10.1016/j.jcz.2019.06.007

George S. \& Martens K. 2002. On a new species of Potamocypris (Crustacea, Ostracoda) from Chalakkudy River, Kerala (India), with a checklist of the Potamocypris-species of the world. Zootaxa 66: 1-15. https://doi.org/10.11646/zootaxa.66.1.1

Halse S.A. \& Martens K. 2019. Four new genera and five new species of 'Heterocypris' from Western Australia (Crustacea, Ostracoda, Cyprinotinae). European Journal of Taxonomy 493: 1-35. https://doi.org/10.5852/ejt.2019.493

Higuti J. \& Martens K. 2012. On a new cypridopsine genus (Crustacea, Ostracoda, Cyprididae) from the Upper Parana River Floodplain(Brazil).Zootaxa 3391:23-38. https://doi.org/10.11646/zootaxa.3391.1.2

Horne D.J. \& Smith R.J. 2004. First British record of Potamocypris humilis (Sars, 1924), a freshwater ostracod with a disjunct distribution in Europe and southern Africa. Bollettino della Società Paleontologica Italiana 43 (1-2): 297-306.

Karanovic I. 1999. On Pseudocypridopsis n. gen., with a redescription of Pseudocypridopsis clathrata (Klie, 1936) and a first description of the male (Ostracoda, Cypridopsinae). Bulletin Zoölogisch Museum 17 (1): $1-7$.

Karanovic I. 2000. Pseudocypridopsis petkovskii sp. nov., a stygobiont freshwater ostracod (Crustacea, Ostracoda, Cypridopsinae) from Montenegro (SE Europe). Mitteilungen aus dem Hamburgischen Zoologischen Museum und Institut 97: 59-66.

Klie W. 1936. Ostracoden aus Kamerun. Revue de Zoologie et de Botanique africaines 28: 287-309.

Martens K. 1987. Homology and functional morphology of the sexual dimorphism in the antenna of Sclerocypris Sars, 1924 (Crustacea, Ostracoda, Megalocypridinae). Bijdragen tot de Dierkunde 57 (2): 183-190.

Martens K., Schwartz S., Meisch C. \& Blaustein L. 2002. The non-marine Ostracoda (Crustacea) of Mount Carmel (Israel), with taxonomic notes on Eucypridinae and circum Mediterranean Heterocypris. Israel Journal of Zoology 48: 53-70. https://doi.org/10.1560/BMTF-KFFG-076V-3M0J

Meisch C. 2000. Freshwater Ostracoda of Western and Central Europe. In: Schwoerbel J. \& Zwick P. (eds) Süßwasserfauna von Mitteleuropa 8 (3): 1-522. Spektrum Akademischer Verlag, Heidelberg, Berlin.

Meisch C., Smith R.J. \& Martens K. 2019. A subjective global checklist of the extant non-marine Ostracoda (Crustacea). European Journal of Taxonomy 492: 1-135. https://doi.org/10.5852/ejt.2019.492

Müller G.W. 1898. Ergebnisse einer zoologischen Forschungsreise in Madagaskar und Ost-Afrika 18891895 von Dr. A. Voeltzkow: Die Ostracoden. Abhandlungen der Senckenbergischen Naturforschenden Gesellschaft 21: 255-296.

Rome D.R. 1965. Ostracodes. Parc National de I'upemba. Mission G.F. Witte 69 (1): 3-71.

Sars G.O. 1910. Zoological results of the third Tanganyika Expedition, conducted by Dr. W.A. Cunnington, 1904-1905. Report on the Ostracoda. Proceedings of the Zoological Society of London 54: 732-760.

Sars G.O. 1924. The fresh-water Entomostraca of the Cape Province (Union of South Africa). Part II: Ostracoda. Annals of the South African Museum 20: 105-193.

Available from https://www.biodiversitylibrary.org/page/40651140 [accessed 26 Mar. 2020]. 
Savatenalinton S. 2015. On three new species of non-marine ostracods (Crustacea: Ostracoda) from Northeast Thailand. Zootaxa 3914 (3): 275-300. https://doi.org/10.11646/zootaxa.3914.3.3

Savatenalinton S. 2017a. A new genus and four new species of subfamily Cyclocypridinae (Crustacea, Ostracoda) from Thailand. Zootaxa 4243 (2): 329-365. https://doi.org/10.11646/zootaxa.4243.2.4

Savatenalinton S. 2017b. Siamopsis gen. nov. and five new species of the subfamily Cypridopsinae Kaufmann, 1900 (Crustacea: Ostracoda) from Thailand. European Journal of Taxonomy 384: 1-39. https://doi.org/10.5852/ejt.2017.384

Savatenalinton S. 2018a. New genus of subfamily Cypridopsinae Kaufmann, 1933 (Crustacea: Ostracoda) from Thailand. European Journal of Taxonomy 487: 1-17. https://doi.org/10.5852/ejt.2018.487

Savatenalinton S. 2018b. Two new species of Cypretta Vávra, 1895 (Crustacea, Ostracoda) from Thailand and a discussion of the genus. Zootaxa 4532 (4): 483-502. https://doi.org/10.11646/zootaxa.4532.4.2

Savatenalinton S. \& Martens K. 2008. Redescription of Hemicypris mizunoi Okubo, 1990 (Crustacea, Ostracoda) from Thailand, with a reassessment of the validity of the genera Hemicypris and Heterocypris. Bulletin van het Koninklijk Belgisch Instituut voor Natuurwetenschappen, Biologie 78: 17-27.

Savatenalinton S. \& Martens K. 2009. Generic revision of Cypricercinae McKenzie, 1971 (Crustacea, Ostracoda), with the description of three new genera and one new species and a phylogenetic analysis of the subfamily. Hydrobiologia 632 (1): 1-48. https://doi.org/10.1007/s10750-009-9826-5

Savatenalinton S. \& Suttajit M. 2016. A checklist of recent non-marine ostracods (Crustacea: Ostracoda) from Thailand, including descriptions of two new species. Zootaxa 4067 (1): 1-34.

https://doi.org/10.11646/zootaxa.4067.1.1

Schäfer H.W. 1952. Über Süßwasser-Ostracoden aus der Türkei. Hidrobiologia, İstanbul Üniversitesi Fakültesi Hydrobiologia Araşt Enst Yayin, Serie B 1: 7-32.

Vávra V. 1897. Die Süßwasser-Ostracoden Deutsch-Ost-Afrikas. Deutsch-Ost-Afrika 4 (2/3): 1-28.

Victor R. \& Fernando C.H. 1981a. A new freshwater ostracod (Crustacea, Ostracoda) from Batu Caves, West Malaysia, with the description of Batucyprettinae new subfamily. Canadian Journal of Zoology 59 (3): 405-414. https://doi.org/10.1139/z81-059

Victor R. \& Fernando C.H. 1981b. Freshwater ostracods (Crustacea: Ostracoda) of the genus Cypretta Vávra, 1895 from Malaysia, Indonesia and the Philippines. Internationale Revue der gesamten Hydrobiologie 66 (3): 415-433. https://doi.org/10.1002/iroh.19810660312

Victor R. \& Fernando C.H. 1981c. Freshwater ostracods (Crustacea: Ostracoda) of the genus Strandesia Vávra, 1895 from Malaysia, Indonesia and the Philippines. Archiv für Hydrobiologie, Suppl. 58 (4): 469-522.

Manuscript received: 27 August 2019

Manuscript accepted: 7 February 2020

Published on: 21 April 2020

Topic editor: Rudy Jocqué

Desk editor: Danny Eibye-Jacobsen

Printed versions of all papers are also deposited in the libraries of the institutes that are members of the EJT consortium: Muséum national d'histoire naturelle, Paris, France; Meise Botanic Garden, Belgium; Royal Museum for Central Africa, Tervuren, Belgium; Royal Belgian Institute of Natural Sciences, Brussels, Belgium; Natural History Museum of Denmark, Copenhagen, Denmark; Naturalis Biodiversity Center, Leiden, the Netherlands; Museo Nacional de Ciencias Naturales-CSIC, Madrid, Spain; Real Jardín Botánico de Madrid CSIC, Spain; Zoological Research Museum Alexander Koenig, Bonn, Germany; National Museum, Prague, Czech Republic. 